
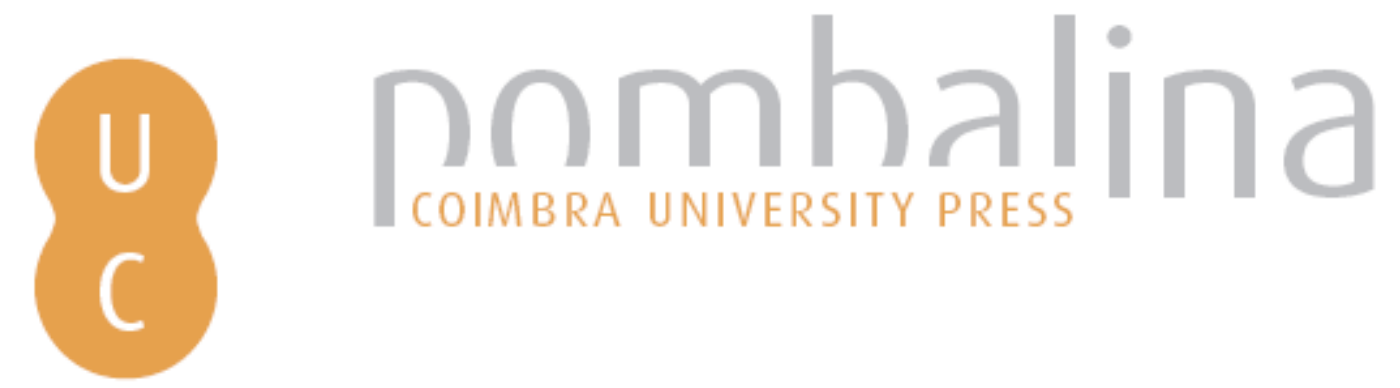

\title{
Unexpected death following femoral catheterization
}

$\begin{array}{ll}\text { Autor(es): } & \text { Suárez-Peñaranda, J. M.; Muñoz-Barús, J. I.; A. Ortiz, J.; Rodríguez- } \\ \text { Calvo, M. S.; Concheiro, L. }\end{array}$

Publicado por: Imprensa da Universidade de Coimbra

URL

persistente: URI:http://hdl.handle.net/10316.2/31738

DOI: $\quad$ DOI:http://dx.doi.org/10.14195/978-989-26-0173-1_68

Accessed : $\quad$ 26-Apr-2023 13:33:02

A navegação consulta e descarregamento dos títulos inseridos nas Bibliotecas Digitais UC Digitalis, UC Pombalina e UC Impactum, pressupõem a aceitação plena e sem reservas dos Termos e Condições de Uso destas Bibliotecas Digitais, disponíveis em https://digitalis.uc.pt/pt-pt/termos.

Conforme exposto nos referidos Termos e Condições de Uso, o descarregamento de títulos de acesso restrito requer uma licença válida de autorização devendo o utilizador aceder ao(s) documento(s) a partir de um endereço de IP da instituição detentora da supramencionada licença.

Ao utilizador é apenas permitido o descarregamento para uso pessoal, pelo que o emprego do(s) título(s) descarregado(s) para outro fim, designadamente comercial, carece de autorização do respetivo autor ou editor da obra.

Na medida em que todas as obras da UC Digitalis se encontram protegidas pelo Código do Direito de Autor e Direitos Conexos e demais legislação aplicável, toda a cópia, parcial ou total, deste documento, nos casos em que é legalmente admitida, deverá conter ou fazer-se acompanhar por este aviso.

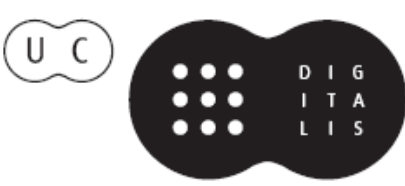




\section{Duarte Nuno Vieira Anthony Busuttil \\ Denis Cusack • Philip Beth}
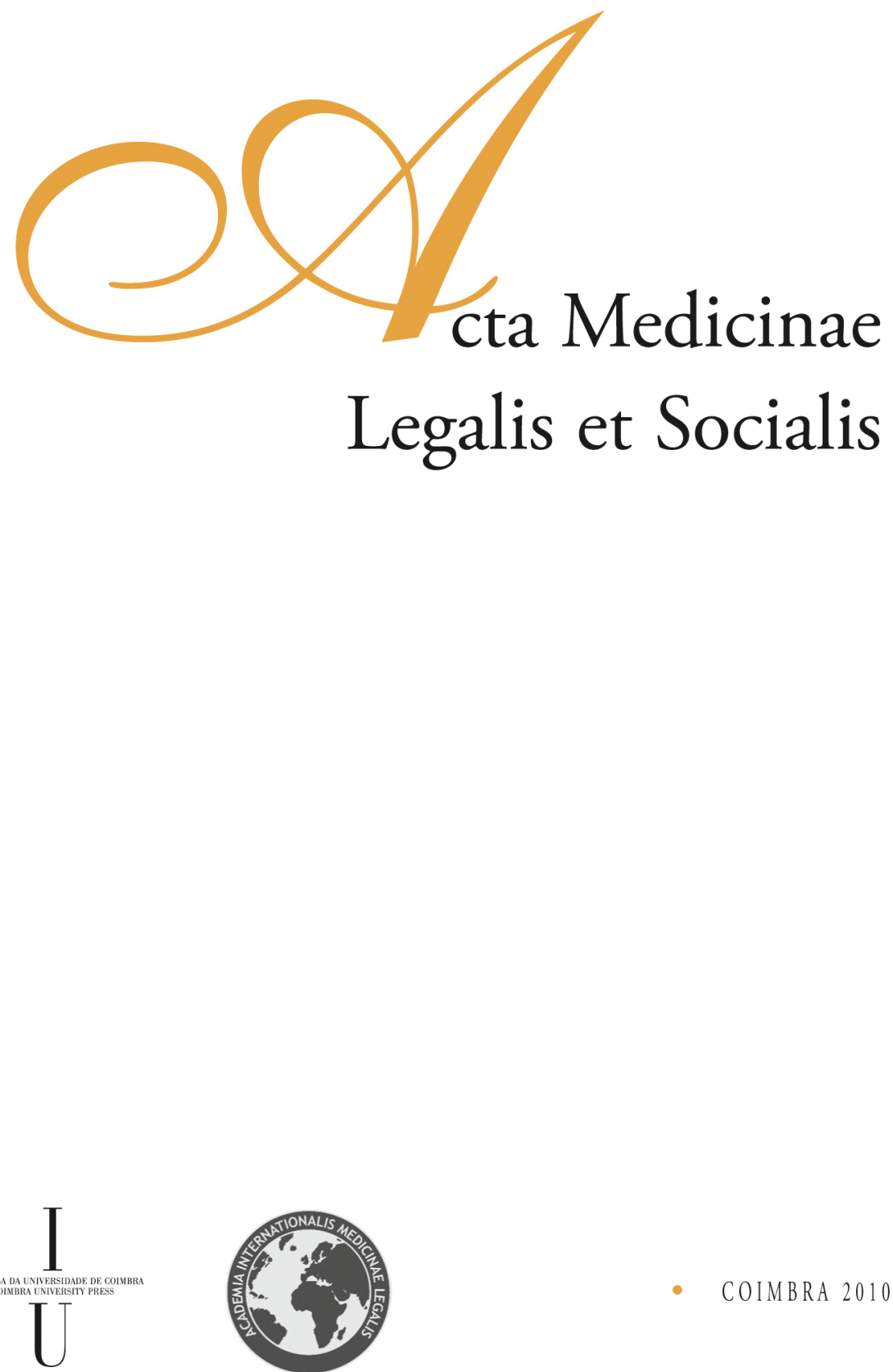
J. M. Suárez-Peñaranda ${ }^{1}$, J. I. Muñoz-Barús ${ }^{1}$, J. A. Ortiz ${ }^{2}$, M. S. Rodríguez-Calvo ${ }^{1}$, L. Concheiro ${ }^{1}$

${ }^{1}$ Department of Pathology and Forensic Sciences, University of Santiago de Compostela, Spain

${ }^{2}$ Department of Pathology, Hospital Xeral-Cies, CHUVI, Vigo, Spain

\title{
UNEXPECTED DEATH FOLLOWING FEMORAL CATHETERIZATION.
}

\begin{abstract}
Investigation of unexpected deaths related to diagnostic or therapeutic procedures is one of the most difficult fields of Legal Medicine. Technical and clinical knowledge is crucial to enable the relatives of the deceased to perceive the independence and neutrality of the investigative process

We report a case of an unusual complication following a catheterism in the lower limbs, which ended with the death of a patient.
\end{abstract}

\section{Introduction}

Investigation of unexpected deaths related with diagnostic or therapeutic procedures is one of the most difficult fields of Legal Medicine. The role of clinical and forensic pathologists is not well established and while one can think that is into the field of the later, others can argue that they do not have the independence necessary to carry out such type of procedures. Technical and clinical knowledge is crucial as it is the perception of the independence of the investigative process by the relatives or the deceased.

We report a case of an unusual complication following a therapeutic catheterism in the lower limbs that ended with the death of a patient. We expect to contribute to a better understanding of the difficulties inherent to an investigation like this and we conclude that the knowledge of the risks following diagnostic and therapeutic techniques is helpful for all pathologists, whatever their preferential dedication may be.

\section{Case report}

A 70-year old man is admitted to the hospital for pain in the lower limbs of sudden onset. He had a previous episode the previous week for a respiratory infection that was completely resolved. This new episode is considered independent form the later and he is diagnosed of arterial ischemia. An emergency catheterism is decided to remove an arterial obstruction in both femoral arteries (Fig. 1). The procedure results in complete disappearance of the pain, but the condition of the patient worsens progressively. 
Since there is no clinical explication for that, an extensive clinical and analytical investigation is performed. Blood analyses reveal a persistent and progressive drop of red cells count and hemoglobin. Hemoglobin levels are 16,1 gr/L in the morning before surgery and 15,9 immediately after surgery. Since then, they fall to 7,9 and 4,4 two and three days after surgery, respectively. Hematocrit values are 47,9, 43,8, 25 and $14 \%$, for the above-mentioned hemoglobin figures. Other analytical findings were not relevant. Abdominal ultrasonography is suspicious for splenic rupture and CT scan cannot rule out this possibility (Fig. 2).

With these data, the patient is submitted to an exploratory laparotomy that rule out abdominal bleeding. The surgeon can visualize satisfactorily the spleen, which is not ruptured or bleeding. The condition of the patient continues worsening and death occurs one week later without a firm clinical diagnosis. Clinical autopsy is authorized.

External examination shows an extensive hemorrhage in the lower right limb and the right and posterior abdominal wall. Internally, massive hemoperitoneum (about 2,5-3 L of blood were collected at autopsy) and an extensive bleeding in the retroperitoneum and the right inguinal soft tissues are the most noticeable findings. The later is considered responsible of the analytical alterations prior to the exploratory laparotomy. Although, the precise amount of blood accumulated in the soft tissues cannot be estimated accurately, a considerable volume can be inferred from the gross examination and it is later confirmed histopathologically. Moreover, histopathological examination of the right femoral artery disclosed persistence of the hemorrhage in the arterial injury related with the catheterism (Fig. 3).

The hemoperitoneum was caused by spleen rupture that was originated in multiple infarctions.

The remaining findings of autopsy were related to the shock developed along the last days of life, mainly Adult Distress Respiratory Syndrome and liver centrozonal hemorrhage.

\section{Comments}

Unexpected deaths following diagnostic or therapeutic procedures may arise the possibility of medical malpractice and, sometimes, such cases may be submitted to medico-legal autopsy. Though, it is not clear if this kind of deaths should be investigated by forensic or clinical pathologists, both of them may be involved occasionally in this kind of investigation. Consequently they should be familiar with the risks of most common medical and surgical procedures and be able to lead a postmortem medical examination under these difficult circumstances.

This patient presented an unusual complication resulting from the catheterism performed in the right femoral artery to resolve an acute ischemia. The local problem was eliminated successfully, but the condition of the patient did not improve but persistently deteriorated with any clear symptoms except for the blood analysis abnormalities. These consisted in a progressive fall in the red count values as well as in the hematocrit and hemoglobin figures. Due to ultrasonography and CT scan images, he was submitted to exploratory laparotomy with the suspicious of abdominal bleeding for spleen rupture. But surgery demonstrated that he did not have hemoperitoneum 
and that the spleen was not bleeding. Externally, it was considered non-pathological by the surgeon, who could satisfactorily visualize it during laparotomy. No other source of bleeding in the abdomen was seen, either. The patient shocked and died one week later. Autopsy revealed a recent massive hemoperitoneum that, obviously, was not present in the moment of surgery and cannot be considered responsible for the loss of blood reflected by blood analysis. No other cause of bleeding was found except for the accumulation of blood in the soft tissues of the right thigh ant the abdominal wall. This was already noticeably externally, and autopsy confirmed a large amount of blood was present in this location. Retrospective review of the CT-scan showed that it was present prior to surgery. Histopathological examination of the right femoral artery showed that the injury caused by the introduction of the catheter was not resolved and bleeding persisted. Taking into account all this information, it was concluded that this was the cause of the progressive and persistent loss of blood responsible for the poor situation of the patient. The massive hemoperitoneum, ultimate cause of the death, was a final complication resulting from ruptured splenic infarctions. Its cause may be attributed to the atherosclerotic disease with multiple embolisms, one of them resulting in the lower limb ischemia.

Femoral catheterization is not exempt of complications, both systemic and local, the later much more common. Thrombosis, new emboli and hematomas are the most frequent, but the real incidence of them is not well known. Massive hematoma has been reported in about $0.9 \%$ of cases and it may be a serious complication. Many risk factors for hematoma development have been identified, including advanced patient age, hypertension, large-bore catheters, operator inexperience, poor groin compression after catheter removal, high puncture site, abnormal vessel or graft, and anticoagulantthrombolytic therapy. Except for the age, we have not been able to determine any other risk factor since the technique had any complication.

In summary, we report an unusual complication of a common therapeutic procedure that highlights the difficult inherent to postmortem investigation of intrahospitalary unexpected deaths.

\section{References}

ABURAHMA AF, JARRET K, HAYES DJ, Clinical implications of power Doppler threetridimensional ultrasonography, Vascular, 12(5):293-300, 2004.

AHN S, RUTHERFORD R B, BECKER GJ, COMEROTA AJ, JOHNSTON KW, BURKE DR, Percutaneus ballon angioplasty". In: Cope C, Atlas of interventional radiology, Philadelphia, J B Lippincott Company, 1990.

AHN SS, RUTHERFORD RB, BECKER GJ, COMEROTA AJ, JOHNSTON KW, MCCLEAN GK, SEEGER JM, STRING ST, WHITE RA, WHITTEMORE AD et al, Reporting standards for lower extremity arterial endovascular procedures, J Vasc Surg, 17:1103-1107, 1993.

DORMANDY JA, RUTHERFORD RB, Management of Peripheral Arterial Disease. TransAtlantic Inter-Society Consensus, J Vasc Surg, 31(1):1-296, 2000.

MEDINA JG, Indicaciones de la angioplastia, In: Radiología Intervencionista. Angioplastia en la AOP, Madrid, Marban Libros SL, pp 49-52,1997. 
NORGREN L, HIATT WR, DORMANDY JA, NEHLER MR, HARRIS KA, FOWKES FGR, Inter-Society Consensus for the Management of Peripheral Arterial Disease (TASC II), Eur J Vasc Endovasc Surg, 33:S1-S75, 2007.

RUTHERFORD RB, BECKER GJ, Standards for evaluating and reporting the results of surgical and percutaneus therapy for peripheral arterial disease, Radiology, 181:277-281, 1991.

RUTHERFORD RB, FLANIGAN DP, GUPTA SK, JOHNSTON KW, KARMODY A, WHITTEMORE AD et al, Suggested standards for reports dealing with lower extremity ischemia, J Vasc Surg, 4:80-94, 1986.

TREROTOLA S, KUHLMAN E, FISHMAN K, Bleeding Complications of Femoral Catheterization: CT Evaluation, Radiology, 174:37-40, 1990.

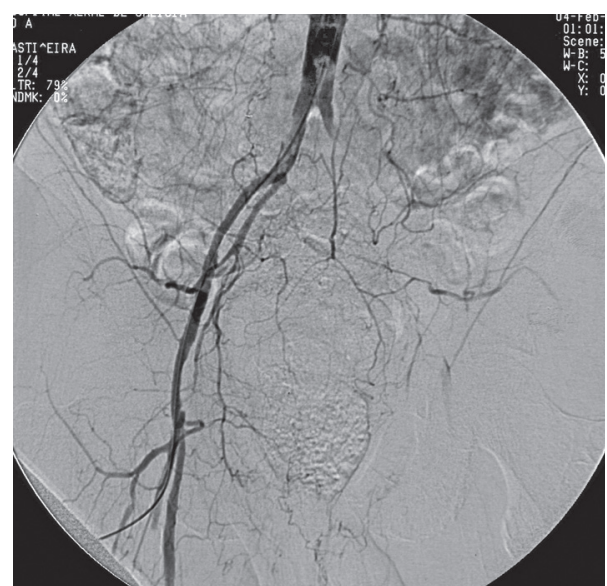

Figure 1 - Arterial ischemia as shown in the lower limb arteriography

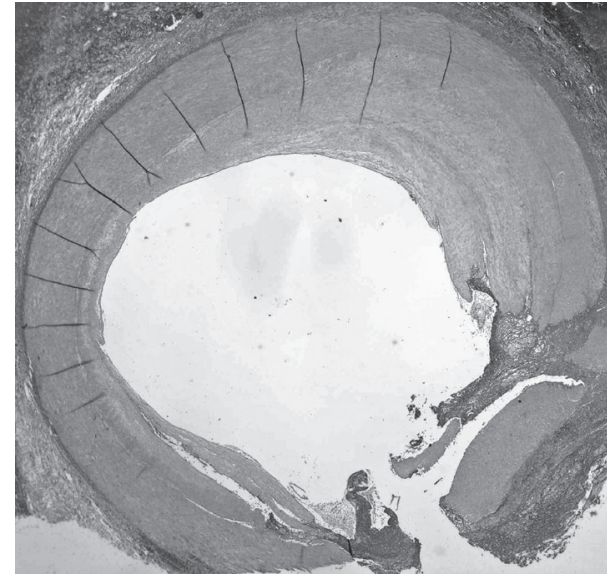

Figure 3 - Histopathological examination of the right femoral artery

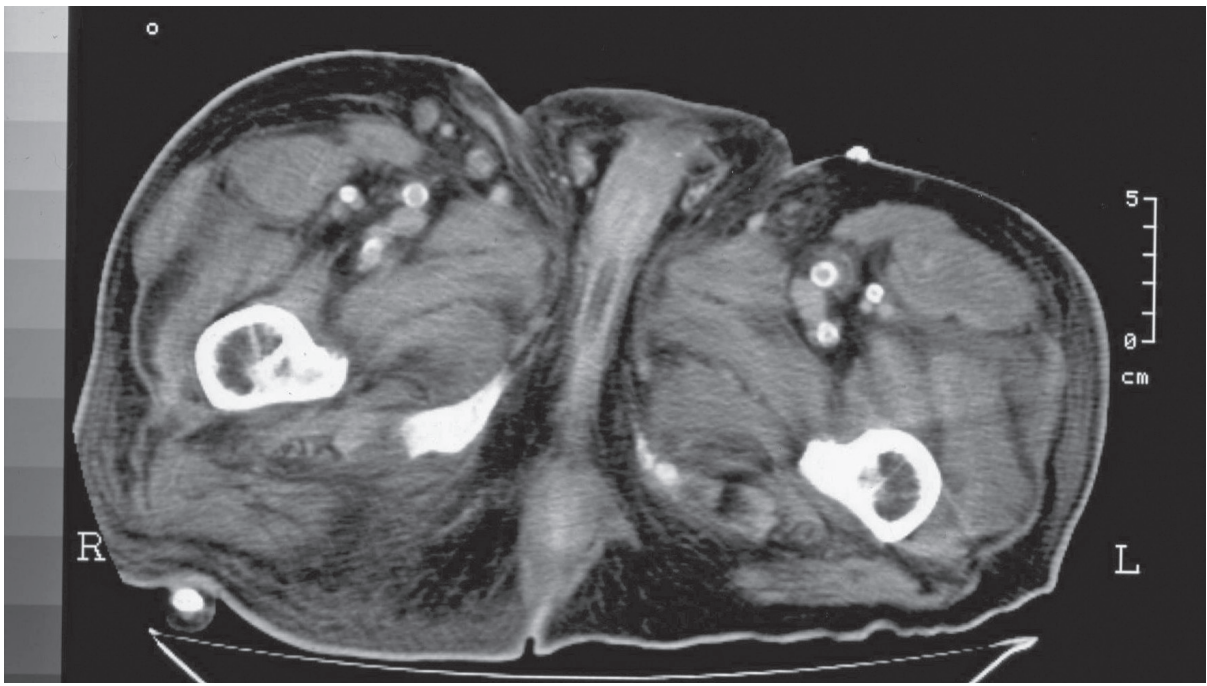

Figure 2 - Extensive hemorrhage in the soft tissues 